 \\ (c) 2020 Reham ElMorally. \\ This is an open access article licensed under the Creative Commons \\ Attribution-NonCommercial 4.0 International License \\ (https://creativecommons.org/licenses/by-nc/4.0/)
}

Received: 8 March 2020 / Revised: 28 April 2020 / Accepted: 1 May 2020 / Published: 10 May 2020

\title{
(De)Legitimizing Violence: Gendering the Arab Spring - A Comparative Analysis of Institutions in Egypt and Tunisia
}

\author{
Reham ElMorally \\ Department of International Development, \\ School of Policy and Development, University of Reading, \\ Whiteknights, PO Box 237, Reading RG6 6AR, United Kingdom
}

Doi: 10.36941/mjss-2020-0027

\section{Abstract}

The Arab Spring (2011) was characterized by uprisings in various Arab countries that attempted to oust their respective regimes. The revolutions diffused from the movement in Tunisia to the rest of the Arab countries. The Arab Spring was followed by what is now commonly known as the Arab Winter, i.e. the resurgence of the authoritarian and oppressive regimes and array of radicalization. This research attempts to compare and contrast the uprisings in Egypt, which is considered a failed story, and Tunisia, which is considered a success story. The underlying question is: what are the institutional and social structures that exist in the respective countries that have amounted to their success/failure? The hypothesis is that Tunisia's social and institutional configurations are more gender conscious than Egypt's, leading to a stronger and more resilient superstructure that encapsulated the aggregate of the population instead of lobbying for the interests of the social hegemonic blocs. In other words, Tunisia's society might be more aware of the bargaining power the historically marginalized women have in ousting the regime, as opposed to the Egyptian population. This awareness is reflected in the structure of political institutions, the power dynamics within those institutions, and affects the selection and orientation of decision-makers.

Keywords: Gender Conscious Institutions, Arab Spring, Structural Violence, Civilian Rights, Egypt, Tunisia

\section{Introduction}

"A wise woman wishes to be no one's enemy, a wise woman refuses to be anyone's victim"

- Maya Angelou'

The Arab Spring (2011) was characterized by uprisings in various Arab countries that attempted to oust their respective regimes. The revolutions diffused from the movement in Tunisia to the rest of the Arab countries. The Arab Spring was followed by what is now commonly known as the Arab Winter, i.e. the resurgence of the authoritarian and oppressive regimes and array of radicalization. This research attempts to compare and contrast the uprisings in Egypt, which is considered a failed story, and Tunisia, which is considered a success story. The underlying question is: what are the institutional and social structures that exist in the respective countries that have amounted to their success/failure? The hypothesis is that Tunisia's social and institutional configurations are more gender conscious than Egypt's, leading to a stronger and more resilient superstructure that

\footnotetext{
${ }^{1}$ Angelou, Maya (1994). Phenomenal Woman: Four Poems Celebrating Women. (New York: Random House).
} 
encapsulated the aggregate of the population instead of lobbying for the interests of the social hegemonic blocs. In other words, Tunisia's society might be more aware of the bargaining power the historically marginalized women have in ousting the regime, as opposed to the Egyptian population. This awareness is reflected in the structure of political institutions, the power dynamics within those institutions, and affects the selection and orientation of decision-makers.

This research is divided into three major parts. The first part will review existing literature regarding the benefits of gender-conscious institutions and the extent to which they reflect sociopolitical realities. The second part provides a brief account of gender-dynamics in both countries for the sake of historical reflexivity and its pivotal significance in shaping the 2011 revolutions. The third is divided into two parts: 1) setting the scene, i.e. provide an account of violence during the Arab Spring in both countries respectively; and 2) espouses an analytical investigation into the legislative, penal- and personal status codes to reflexively analyze the effect of descriptive and substantive representation within them. The fourth part will engage with contemporary issues within both countries, in hopes to provide an alternative perspective and substantiate the argument, that genderconscious institutions have played a crucial role in the success of the Tunisian revolution, and the lack thereof, to its failure in Egypt. The research ends with concluding remarks on how hegemonic masculinities with both countries have led to their respective success and failure.

This research hopes to shed light on some of the factors contributing to why the Arab Spring may have succeeded in some nations and failed in others. The objective is to illuminate and inform of the significance of a gender equality and equity for social and political sustainability, change, and efficacy. The importance of feminist movements is still underrated in political struggles as they are believed to be different and divergent, while in fact they are intertwined. I intend to emphasize that the feminist struggle is inseparable from the revolutionary ambitions, as half of the population cannot affect change, but maybe if all members of a society solidify their objectives a true revolution will take place.

\section{Why Use Gender as a Framework of Analysis?}

Gender analyses and its incorporation in academic research has proven critical to most academic writing, as observed in the world we are currently experiencing. The significance of gender is its determining ability to impute who "who goes hungry and who gets adequate nutrition and water, who can vote, run for office, marry, or have rights to children, who commands authority and respect and who is denigrated and dismissed, and who is most vulnerable to violence and abuse in their own homes and intimate relationships" (Waylen, Celis, Kantola and Weldon, 2013:2). The socio-economic, political, and sometimes even livelihood of persons depends on the integration of gendered analyses for enhanced policy making. Gendered analyses are thus crucial and relevant theoretical lenses researchers adopt to adequately reflect, report, and analyze institutions. It is additionally the reason this research is discussing gender consciousness and gender conscious institutions in the post-Arab Spring era. The term gender conscious institutions, in this paper, is meant to refer to two things: first, the structure of the institutions itself, using descriptive statistics to understand how symbolic and substantial representation (Pitkin, 1972) have affected policy construction and the general political atmosphere in Egypt and Tunisia; Second, it refers to the capacity of institutions, within Egypt and Tunisia, to accommodate for a historically marginalized group, pertaining that an increase in the institutional capacity and its consciousness of gender-based shortcomings would ultimately yield a politically stable environment, encompassing of all members of society, even in the aftermath of revolutions.

The Arab Spring has confronted Western perception of Arab, Muslim women by opposing the continuous perception of them as "victims, oppressed, [and] having little agency" (Joseph, 2012:10) and challenging the idea that Muslim women "need saving" (Abu-Lughod, 2002). The world was shocked to witness women marching on the streets of Cairo and Tunis, as women from all realms of society, of all ages and social classes, took their grievances to the streets in an unprecedented manner 
(Giacomo, 2012). The Arab Spring emphasized a unison between the divergent segments of society, where differences were set aside and the focus on achieving a common goal - 'dignity', 'freedom', and 'social equality', to be a fundamental right to all citizens of society and calls for corruption, statesponsored police brutality and torture, and structural reform - were elevated and pronounced. The revolutions in Tunis and Cairo specifically challenged the generation-old social custom that "mixing in public places appeared to be temporarily forgotten and gender roles suspended" (JohanssonNogués, 2013:394). Nawal El Saadawi, an Egyptian feminist ostracized and exiled for her, supposed, radical views, returned from her exile to participate in the revolution, saying "I felt for the first time that women are equal to men" (Cooke, 2015). Furthermore, the anti-government sentiments motivated Amal Abdel Hadi, in an interview with International Federation of Human Rights, to say "women and men were comrades in the protests. This was an incredible, incredible time in Egypt. Millions of people were gathered in the same place. And women were not afraid ... there was a sense of [male demonstrators'] complete respect, complete support, and complete solidarity towards the women" (FIDH, 2011). Likewise, in Tunis, the "January revolution illustrated that men and women had equal stakes in the transformation of their political and social reality and were equally committed to bringing about that change" (Mulrine, 2011:18).

The Arab Spring has brought about some unexpected consequences for its female participants. The women who were supported, heard, and, in some instances, idealized as icons for the revolutionary movements in Tunis and Cairo, are now attacked by their respective regimes. This, in turn, has "invited some observers to draw pessimistic parallels between the Arab Spring and the setbacks in women's rights in the aftermath of other regime overthrows such as the Iranian Revolution of 1979, the 1919 Egyptian anti-colonialist struggle or the case of the Algerian War of Independence in 1962" (Johansson-Nogués, 2013:394). Successively, a sudden disenchantment of women as equal party in the struggle for change in the society was observed, and hostility by 'revolutionary brothers' towards women in the aftermath of the revolutions was recorded (Mhajne and Whetstone, 2018:64). The reasons of this, as will be argued in this research, is gender-based expectations supported by a pre-ascribed performativity and institutionalized patriarchy in Egypt and Tunisia's polity. By closely investigating institutional apparatuses, this research will deconstruct gender-conscious institutions and their effects on the outcome of the revolutions in Egypt and Tunisia. The purpose of the article is to highlight how a gendered analysis to government structures can enhance or undermine political struggle. The underlying belief is that institutions provide the structure and the guarantee for members of society, arguing that a lack of resilient and supportive institutions that protect all members of a society, not just the selective hegemonic blocs, will leave the already historically marginalized exposed to abuse, exploitation, and violence.

\section{Gender Relations in Egypt and Tunisia - Pre-Arab Spring}

Egypt was declared a de jure independent country in 1921 after three years of protesting British rule and governance and declared a British veiled protectorate (Tignor, 1966:370). Nonetheless, British forces and political influence was still very much present in the country until the 1952 revolution led by the Free Officers (Gordon, 1992:59). The status of women within the Egyptian society was weak, where women were confined to the private sphere in the face of reactionary Isalmist movements as well as hegemonic social blocs, although female figures, such as Huda Shaarawi ${ }^{2}$ and Duriya Shafiq ${ }^{3}$, were visibly present and actively participating in the 1919 and the 1952 revolutions, women did not gain suffrage or the right to run for parliamentary elections until 1956. In 1960, Egypt's former

\footnotetext{
${ }^{2}$ 1879- 1947 was an "Egyptian feminist who removed her veil publicly in a rejection of the harem system which kept girls and women separate from men" (Hawkins, 2018).

${ }^{3}$ 1908-1975 was an Egyptian feminist and activist who "in the early 1940s at an international conference in London. In 1951 she led an army of women as they stormed onto the floor of Egypt's all-male parliament demanding their rights" (Kirkpatrick, 2018) and was successful in gaining women suffrage in 1956.
} 
president Gamal Abdel-Nasser attempted to reform the Personal Status Law (PSL), which had not been revisited since its formulation in 1923 in relation to women's rights, yet abandoned the initiative altogether when opposition, from males within the society and Islamists alike, grew.

When Mubarak came to power in 1981, he introduced some minor changes to the PSL, specifically he amended the divorce laws, child custody regulations, and installed harsher alimony rules (Tadros, 2010:90). In 2009, during Mubarak's reign, secondary education was universalized and quotas for and parliamentary representation constitutionally granted through amendments to the electoral law (64/454 seats were reserved for women in the National Assembly). The lack of an adequate superstructure to represent and protect the rights and stipulate the obligations of women, the marginalized of the society have been exposed to various forms of restrictions, underemployment, lack of visibility in the public sphere, and discrimination on the basis of sex. This objectification and dismissal, in turn, resulted in the confinement of women in the private sphere, their exclusion from their right to determine their personal fates as well as that of the state, and unprotected from gender-based violence in the private sphere.

Tunisia gained independence from the French in 1956 after two years of negotiations between national representatives, supported by the unions, and the French for the establishment of a new constitution (Goulding, 2011; Grami, 2008). As of independence Tunisia has witnessed "a process of state-led secular social reform to become at once one of the most socially-progressive and politicallyauthoritarian countries in the Arab world" (Black, 2010). Tunisia's then president, Habib Bourguiba, perceived female empowerment and development critical for the economic growth and restructuring of the newly-independent nation (Gami, 2018:26). Bougruiba's state-sponsored feminism situated Tunisia ahead of most of its Arab counterparts during that period, as it was "instrumental to the project of Tunisian national development that the ruling elites had in mind" (Dalmasso and Cavatorta, 2010:221). Furthermore, Tunisia distinguished itself from its Arab counterparts by establishing a Personal Status Code in 1956, which does not adhere to the rulings of Shari'a Islam as most of the Arab World; the abolishment of polygamy, the equal rights to divorce and child custody in the eyes of the law irrespective of gender or social norm, and the right to suffrage and political representation (in 1957).

Furthermore, in 1958 the Tunisian government universalized education for all members of the society, and made mandatory in 1991 under Zine El Abdine Ben Ali (Rose, 2015:5). Furthermore, it has been noted that Tunisia has outranked many of its Arab counterparts in parliamentary representation ( $28 \%$ of seats were occupied by women) while being in a "dictator controlled assembly" (JohanssonNogués, 2013:397). Yet, this overwhelming and superficial figure does not automatically translate to enhanced and significant women's rights reform, but can be seen as an exploitative mechanism by the state to obtain international standing and consequentially encourage foreign direct investment and combat international scrutiny on human rights abuses. As one author noted "the primary function of the [women's rights] organizations ... was to be a tool of public relations to portray an image of the Tunisian state and civil society as being amiable towards women's interests" (Mulrine, 2001:13). Therefore, if the state-sponsored feminism project had truly been as affective as the figures suggest, Tunisian female dissidents would not have expressed grief to the inadequate protection against different forms of gender-based violence (domestic violence being of utmost importance, and the least publicly and institutionally addressed), the lack of economic independence, and the general status of females in the society, during the 2011 uprising.

The Freedom House produces an annual report discussing the level of freedom in each country. According to their 2018 reports, Tunisia scored 70/100 on the freedom index earning it the label 'free', and Egypt 26/10o earning it the label 'not free'. The statistic for each country are calculated based on Political Rights and Civil Liberties (each divided into a multitude of subsections including: a) voting processes, b) diversity in political participation and presence, c) governmental operationality and functionality, d) liberty to express one's views and beliefs e) the right of organizations and establishment of association, f) rule of law, and, g) Invidia rights and liberties as prescribed in Human 
Rights Conventions such as Article 5 of the European Convention on Human Rights ${ }^{4}$ ). in the Freedom house report of 2011 however, both countries were labeled as 'not free' and scored $7 / 7$ ( $1=$ best, $7=$ worst) on political rights, and 5/7 on civil liberties (Freedom House, 2011a; Freedom House, 2011b). The question now remains, what structural changes have been undertaken in Tunisia to earn it its new standing as 'free' versus Egypt, which remained 'not free'? The data suggest institutional reconfiguration and restricting in Tunisia as opposed to Egypt which maintained its authoritarian personal rule. It could be argued that Tunisia's success can be attributed to its newfound willingness to incorporate and listen to its opposition, specifically Islamists. By coopting the opposition into the government apparatus, Tunisia has giving way to political pluralism to rise. It was argued that Tunisia had "laid the political and constitutional foundations necessary for the rise of democracy and the rule of law" (Mansouri and Armillei, 2016:159). Nonetheless, both countries scored atrociously low, Egypt 3/12 and Tunisia 6/12, on the functioning of government (Freedom House, 2018a; Freedom House, 2018b). This begs the question: when does incorporation insinuate democratic strife and when does it insinuate an attempt to co-opt an entity for supervision and control?

Some research recognized Tunisia's Spring as a success and Egypt's Spring as a failure (Khlebnikov, 2016; Goldstone, 2011; Brown, 2013; Stepan, 2012; Yahya, 2016). Both countries adopted different strategies towards their opposition; Egypt's government has set increasingly restrictive laws on the formation, activity, and legitimization of political opposition, while Tunisia reformed its legal framework to conceive of opposition as a natural and integral part of its configuration, rather than a threat. This approach might be attributed to Tunisia's colonial history, and could therefore be viewed as cultural mirroring of how integral opposition is to deter from repression, in the 1950 from colonial powers, and in the 2010 s from unjust authoritarians. To answer the question more adequately: The incorporation of political opposition in Tunisia was strategically informed, as the country has a longstanding history of defying 'traditional' forms of rulership in the Arab world; Egypt on the other hand, used the technique of divide and rule to not only crush its opposition, but to deregulate and delegitimize their establishment in the first place. These two countries, due to their different political histories - Egypt has a long history of military regimes in power since its de facto independence in 1952, around which the constitution was set up to perpetuate and reproduce the status of the military as the hegemonic bloc, while Tunisia has experienced a civilian rule since its independence 1956, with a lawyer as the first formal president of the country, whose played a key role in negotiating the constitution with the French by which the society was governed and independence was achieved - have experienced and approached political opposition differently.

Political Islam has gained momentum since the beginning of the $21^{\text {st }}$ century and influenced public opinion as well as decision making processes. The Muslim Brotherhood, for example, was founded by Sayyid Qutb in Egypt, in the 1920s, and has firmly established a reactionary and political opposition force in Egypt, which disseminated through the Arab World. The relationship between political Islamists, fundamentalists and the government in both Egypt and Tunisia has created some intra- and inter-state conflict. Secularization and pan-Arab movements in the 196os and 7os forced much of these movements underground. The use of the coercive apparatus in many Arab countries to crush opposition is not uncommon or peculiar, especially to the citizenry. Authors noted that in Arab countries "Our authoritarian regimes-or at least the bulk of their citizens-may all be unhappy, but in very different ways" (Anderson, 2011: 5), as "co-option and coercion ... were the tools of choice; liberalizing measures tended only to produce 'democratic façades”" (Fawcett, 2017:804), thereby “... the state's capacity to maintain monopoly on the means of coercion ... if the state's coercive apparatus remains coherent and effective, it can face down popular dissatisfaction and survive significant illegitimacy ... and even a pervasive sense of relative deprivation among its subjects"(Bellin, 2004:143). As mentioned above, different governments reacted differently to these forces. How religion, as an institution shaped the Arab Spring experience in these countries, is discussed later in the paper.

${ }^{4}$ European Convention on Human Rights (2019). "Right to Liberty and Security". European Court of Human Rights, (accessed online): https://www.echr.coe.int/Documents/Guide_Art_5_ENG.pdf 


\section{Women in Tunisia and Egypt - During the Arab Spring}

It is not uncommon for regimes to support a social group for the advancement of their own agenda. Authoritarian regimes, in particular the personalization of the government by authoritarian rulers, in Egypt and Tunisia have utilized women's movements to the extent where it served their interests, and cracked down on them when their utility proved insufficient for their political agenda (Sika and Khodary, 2012:98). As one author noted, “women's participation is rewarded only if the new men in power want to pacify them or the men belonging to their social class, as well as in cases when women are seen as necessary draftees into socio-economic development" (Johansson-Nogués, 2013:395). The interplay between female agency and male concessions during revolutions in authoritarian systems can pose a serious threat to the adequacy of policy and females' subsequent access to decisionmaking platforms. It is therefore crucial to use a gendered analysis as it urges us to critically view "a set of culturally shaped and defined characteristic associated with masculinity and femininity" (Tickner, 1992:7), which are social constructed to maintain the status quo and perpetuate maledomination over the public sphere.

To adequately represent the political dynamics of gender, it is worth discussing the formation and effects of Hegemonic masculinity 5 (Kessler, et al, 1982; Connell, 2005). Hegemonic masculinity is thus a way to ascribe value to the powerful, rich, educated, and urban men within the society. The concept draws our attention to the interest groups within society who benefit from the continuation of gender-binary understandings. Furthermore, it subordinates men and women to a selected few whose power is drawn from their socio-economic stability rather than merit. It therefore allows "models of admired masculine conduct, which may be exalted by churches, narrated by mass media, or celebrated by the state" (Connell and Messerschmidt, 2005:838) to operate unchallenged within the society. For Egypt and Tunisia hegemonic masculinity could be one of the reasons women were targeted by their respective regimes in the aftermath of the Arab Spring. In juxtaposition to hegemonic masculinity, the concept of devalued femininity emerges; "a set of feminine characteristics and behavior that are lauded and held up as a (generally submissive) role model for all women to live up to. The devalued femininity, in essence, constitutes a residual gender category for all those women not in a position to claim a good fit with the hegemonic masculinity's ideals. All gender categories are thus established by and in relation to the valued masculinity, and the socially dominant males act to police gender-role conformity" (Johansson-Nogués, 2013:396).

Conjecturally, the interplay of hegemonic masculinity within Egypt and Tunisia as contrasted with devalued femininity could be an instrument of the state to enforce conformity and police behavior within the public and private spheres. By mobilizing gender-binaries and attributing value, or the lack thereof, on human beings within the society, the state engaged in favoritism and perpetuated marginalization, stigmatization and targeting of 'deviants' and dissidents (Bayard de Volo, 2012). In order for the hegemonic bloc to maintain its status in the society, it resolves to violent tactics, such as, gender-based violence and the selective targeting of the society's most politically vulnerable (the poor the disabled, the women) to rejectionally suppress their movement and protect its privileged position. Stiehm (1982) argued that the division of society into 'protector' and 'protected', here the state is the protector, violence is justified and legitimized. By ideologically cloaking violence exercised by the state as protecting the national interest, the state uses its coercive apparatus to demand "its rules and decisions [are abided by] without questioning, criticizing, or demanding independent review of the decisions" (Young, 2003:14). As women are traditionally the 'protected', the Egyptian as well as the Tunisian governments respectively used its power to accentuate what would happen if it were to withdraw, thereby using fear as a powerful deterrent for

${ }^{5}$ A concept that first appeared in research regarding social inequality in Australian high schools (Kessler, et al, 1982) and further developed by Raewyn Connell, problematizes the small group of men whose authority within a given society subordinate men and women who are perceived to be 'common' or 'weaker'. It justifies why a selected few are entitled to rule, dictate policy, and establish 'accepted' social roles. 
female protestors. This will be discussed further later on in the paper. 'Disciplining' the society utilizing gender-based violence and the overuse of the security and coercive apparatuses allowed Egypt's Hosni Mubarak (for 30 years) and Tunisia's Zine al-Abidine Ben Ali (for 23 years) to remain in power uncontested and unencumbered.

\subsection{The State: Protector or Predator?}

Tunisia is now being singled out as a success story and the only 'free' country in the Arab World. Egypt on the other hand has maintained its status as 'not free' and continues to violate many fundamental rights its population is entitled to (Freedom House, 2018). To a great extent, gender dynamics pre-, during-, and post-Arab Spring have been troubling and disappointing. Tunisia, although it has been "help up as the country where women had acquired the most extensive legal guarantees, both in the private and public realm" (Johansson-Nogués, 2013:398) has, too, failed to protect its citizens during the uprising of 2011.

Since their respective independence, Egypt and Tunisia have instrumentally employed the guise of state-sponsored feminism and the cloak of protectors to maintain and solidify power. Problematically, however, a state-sponsored project will most often be structured in a top-down fashion (Amar, 2011). This transforms the program, in a sense, to an elitist one, which targets the 'valued' members of society first, i.e. the educated, secularized, and wealthy members of the society are the primary beneficiaries of state-sponsored feminism, while the marginalized, those in need of such support, are systematically ignored. The focus of the state on the elite strata of the society, paved the way for other organizations to claim feminism for themselves. One such organization is the Muslim Sisterhood in Egypt, established as sub-organization of the fundamentalist Muslim Brotherhood. The function of such an organization was to counter secular feminist projects, advocated for by the supposedly 'enlightened' and secular women within the society. Seeing how state-sponsored feminism only targeted the minority and not the majority, the Muslim Sisterhood had little to no difficulty infiltrating the society and gaining prominence. Furthermore, secular and socialist feminists such as Doriya Shafiq and Ingy Efflatoun ${ }^{6}$, Malak Hifni Nasif ${ }^{7}$, Huda Shaarawi, Nawal El Saadawi ${ }^{8}$, inter alia, Nabawiya Musa ${ }^{9}$, fell prey to conspiracy theories propagated by the state, reactionary forces, and fundamentalists alike. Many Egyptian feminists were labeled as 'spies of the west', 'psychologically unstable', and 'radical' for their activism and strife for gender equality (Badran, 1991:205). In Tunisia, similarly, secular feminists like Sana Ben Achour ${ }^{10}$, Fatma ChamakhHaddad $^{11}$, and Latifa Lakhdar ${ }^{12}$, were repeatedly attacked by the Muslim Democratic party, Ennahda ${ }^{13}$, for similar reasons (Marks, 2012).

Suspicion of secularization and its pioneers is a longstanding issue in the Arab World. Mohamed Arkoun (1994) argued that the period following the Second World War " was the period of

\footnotetext{
${ }^{6}$ Ingy Efflaton (1924-1989) a Marxist-nationalist-feminist and was a leading artist in contemporary Egyptian art scene Inji Aflatoun was an Egyptian painter and activist in the women's movement.

${ }^{7}$ Malak Hifni Nasif (1886-1918) lecturer and intellectual who influenced Huda Shaarawi and contributed to the advancement of a female political understanding in Egypt..

${ }^{8}$ Nawal El Saadawi (1931- Today) is an Egyptian physician and feminist activist on the role of Islam in the Egyptian society and its influence on the Egyptian Feminist Movement."

${ }^{9}$ Nabawiyya Mohamed Musa (1886-1951) was an educator and a pioneer in the Egyptian Nationalist and Feminist Movements.

${ }^{10}$ Sana Ben Achour (1955- Today) is a Tunisian lawyer, academic, and feminist activists who founded the Women's Refugee Shelter in Tunis.

${ }^{11}$ Chamakh Hadad (1936-2013) delegate member of the National Union of Tunisian Women and activist.

${ }^{12}$ Latifa Lakhdar (1956-Today) operated as the Minister of Culture in Tunis and is an academic in French and Arabic literature in Islamic studies.

${ }^{13}$ Ennahda roughly translates to The Rise, established in 1981 and influenced by the Muslim Brotherhood and the Iranian Revolution.
} 
naïve consciousness, because these generations believed naïvely that it was enough to take "prescriptions" for the success of Western Civilizations and apply them to Muslim countries" (Arkoun, and Lee, 1994:n.d.). He continued to stat that "Secularism was perceived as one of those effective prescriptions to be applied to societies where religion controlled all the happenings and gestures of daily life. Those generations of Muslim intellectuals did not have a sufficient grasp of history to be able to pin down the ideological genesis, sociopolitical functions, and philosophical limits of secularism in the West" (ibid), adding that an application of Western philosophies without the Western mentality has led to the radicalization of the Arab World and the reorientation of many countries to traditional Islamic thought and practice (Arkoun and Lee, 1994:n.d). The argument can be made, that in the absence of an alternative and in the rejectionist atmosphere fueled by anticolonial sentiments, political Islamists found their calling, and thus denunciated anything Westernborn. It is not surprising that female feminist activists were the first ones to fall prey to such denunciations. Although these are historical arguments, their effect is still relevant.

During the Tunisian revolution in 2011, the Ben Ali regime prosecuted "activists were dubbed traitors because they had built coalitions with other feminist groups around the world. They faced harassment and intimidation from Islamists and were subjected to police surveillance. Social networks dismissed them as liberal women of bad reputation and a disgrace to the ideal of a pure Islamic order" (Grami, 2018:35). Egyptian activists faced similar prosecution, as "key obstacles that women's rights activists will face in the months and years to come is a prevalent public perception that associated women's rights activists and their activities with the ex-First Lady, Suzanne Mubarak, and her entourage-that is, with corrupt regime politics in collusion with imperialist agendas" (Elsadda, 2011:86). Moreover, the Muslim Brotherhood, after being elected for office in 2012, argued that secular feminism "eliminates Islamic values, and seeks to destroy the family (...) which would lead to social disintegration", adding that feminists are "destructive tools meant to undermine the family as an important institution" (Ikhwanweb 2013). While some scholars argue that feminism, in Egypt particularly, was born out of nationalist thought (Harouni 1962:215; cited in Philipp, 1978:277), it quickly became clear that nationalism in itself is patriarchal (Badran, 2005:21). The struggle of many women in the Arab world climaxed the wake of the Arab Spring; calls for dignity, reform of the PSL and gender equality, and an end to Violence Against Women (in the public and private sphere) were echoed in almost all uprisings.

For a short period of time, there was hope that a revival of Arab feminism would gain momentum, especially in Egypt and Tunisia, but that ambition was swiftly extinguished. Gendered violence executed by the government to deter women from participating in marches and sit-ins took the streets by surprise, as "she became a powerful testimony of the emptiness of the sitting regime's policies and rhetoric. Rather than collaborating with their alleged protector, such women unequivocally demanded that the regime "go away" (Johansson-Nogués, 2013:399). As more women realized that their perpetrator is in fact the regime guised as protector, the more rebellious they became. This unanticipated response towards the regimes made them engage in gender-based violence. As resistance grew so did the violence. In Egypt and Tunisia gender-based violence was perceived as a strong deterrent for male protestors by the security apparatus. As women are perceived as an extension of their male counterparts, and an attack on them is an attack on the male's honor, the governments adopted the demoralization approach to dehumanize the protestors and maintain their authoritarian regimes in place. In countries where "intensified and generalized [their] practice of targeting publicly and politically active women", the state's responded with "the policy to harass, sexualize and torture them; to impugn their respectability and undermine their status as political subjects or citizens, except where they acted in collaboration with state-legitimized morality and policing campaigns" (Amar, 2011:309). The authoritarian regimes of Tunisia and Egypt had hoped that these forms of targeted violence would render it unthinkable for a woman of respectable status to be a protestor, as a supposedly pious woman, would not willing position herself in situations where her honor, and that of her family, would be threatened or questioned. However, such state measures have been unsuccessful and in fact contributed to the fueling of the revolution. 
In Egypt, on the one hand, the use of the coercive apparatus was almost immediately deployed. State executed violence was not uncommon for the Egyptian population. In the months leading up to the 2011 revolution a "rare, first-hand glimpse of the routine use of brutal force by the Egyptian security forces, who expect to operate in a climate of impunity, with no questions asked" came to light (Amnesty International, 2010). The picture of the brutally tortured 28-year old Khalid Said were symbolic in the months that followed, as protestors routinely raised his picture to signal discontent and urge the Mubarak regime to resign (Hope, 2011). Systemic and unaccounted for violence by the coercive apparatus eventually reached a tipping point, and Khalid Said's violent death is where the Egyptian population reached a tipping point. According to Human Rights Watch arbitrary detentions and violation of fundamental human rights, such as the right to a fair trial, the right to humane interrogations, the absence of torture of citizens in prisons, the absence of freedom of expression, inter alia, the renewal of the emergency law as permissible under Law No. 162 of 1958, are key factors in why the revolts took place (Human Rights Watch, 2011).

Under emergency law, the security forces are allowed to stop and search, to detain persons without pressing charges, and extending the authority to stop and arrest civilians to military forces. The renewal of this de facto Martial Law essentially suspends the constitutional and legal rights of civilians and rests power with the executive. Although the declaration of a state of emergency requires the approval of the National Assembly and is set for a specific time period, the personalized authoritarian rule ${ }^{14}$ in Egypt provides the President with unlimited power. It can be argued that enacting the emergency law in Egypt was not only an infringement of personal rights proclaimed in International Covenants ${ }^{15}$ Egypt signed and ratified, but also provided "sweeping powers to the executive, [and]/or lacked the clarity to ensure the adequate delimitation and separation of power in practice" (International Commission of Jurists, 2012:19). The situation in Egypt did not improve under the "new" post-2011 government of Adel-Fattah El Sisi, and in fact continued to escalated. As the 2017/18 Amnesty International report reported:

\begin{abstract}
"Egypt's human rights crisis continued unabated. The authorities used torture and other ill-treatment and enforced disappearance against hundreds of people, and dozens were extrajudicially executed with impunity. The crackdown on civil society escalated with NGO staff being subjected to additional interrogations, travel bans and asset freezes. Arbitrary arrests and detentions followed by grossly unfair trials of government critics, peaceful protesters, journalists and human rights defenders were routine. Mass unfair trials continued before civilian and military courts, with dozens sentenced to death. Women continued to be subjected to sexual and gender-based violence and were discriminated against in law and practice. The authorities brought criminal charges for defamation of religion and "habitual debauchery" on the basis of people's real or perceived sexual orientation". (Amnesty International, 2018a:152).
\end{abstract}

Gender based violence executed by the security apparatus reached a climax during and after the Egyptian revolution. It was reported that "state-paid thugs who dispersed the demonstrations and reportedly detained at least 19 female protestors. The women were taken to different state dependencies and subsequently subjected to torture sexually degrading treatment and so called virginity tests" (Johansson-Nogués, 2013:400). The most popular and reflective image depicting gender-based violence is that of Ghada Kamal, a 28 -year old protestor and a political activist, who was dragged by security forces and detained. Ghada report "How can the same person who attacks an unarmed woman protect the nation? I was dragged and pulled from my hair. They hit me with batons in my stomach and my chest" (Zayed, 2011). Ghada's story only mirrors a reality for many Egyptian women as "women who protested were sexualized and had their respectability wiped out: not just by

${ }_{14}$ "defined as those regimes where power is highly concentrated in the hands of a single individual ... limited constraints on decision-making in personalist settings means that leaders have the latitude to change their minds at whim, producing volatile and sometimes even erratic policies" (Kendall Taylor, et al, 2017:8)

15 See United Nations Human Rights: Office of the High Commissioner (accessed online): https://treaties.un.org/doc/Publication/MTDSG/Volume\%2oI/Chapter\%2oIV/IV-9.en.pdf 
innuendo and accusation, but literally, by sexually assaulting them in public and by arresting them as prostitutes, registering them in court record and press accounts as sex criminals and then raping and sexually torturing them in jail" (Amar, 2011:309). This account is based on extensive research conducted by El Nadim Center ${ }^{16}$ in 2003-2006 in which testimonies of released detainees were recorded and data regarding the number of victims collected (El Nadim Team, 2006). Samira Ibrahim, then a 24-year old from upper Egypt, faced similar fate to Ghada Kamal. Samira, however, trusted the system and filed charges against security forces for being subjugated to virginity testing and false charges of prostitution. She among other women, was "beaten, given electric shocks, stripsearched and said they were forced into receiving a virginity test, while being humiliated, video-taped and exposed" (Mohsen, 2012). Shortly after, the military doctor, Ahmed Adel, who performed the virginity tests was exonerated by the military court, despite the guilty-rule of another court and admission to guilt by generals (Mohsen, 2012). The institutionalization of patriarchy in Egypt has led many to engage in victim blaming and ad hominem attacks. She was confronted for "exposing the army's methods", and her persona challenged as some say "nice Muslim girls should not participate in street protests in the first place and hence Ibrahim has only herself to blame for what happened" (Johansson-Nogués, 2013:400).

In Tunisia, on the other hand, the use of the coercive apparatus was sporadic and limited, yet by the time the protesters gained significant numbers violence executed by the state targeted individuals. Discursive and physical violence against women left several dead after female lawyers, students, women's organizations, and other professionals organized a peaceful march against perpetual violence by police and security forces (Chrisafis, 2011). In a report, the president of the National Council for Civil Liberties, Sihem Bensedrine, stated the attacks "were random, a sort of reprisal against the people. In poor areas, women who had nothing to do with anything were raped in front of their families. Guns held back the men; the women were raped in front of them" (Chrisafis, 2011a). The same report showed that "In random roundups in poor, rural areas youths were shot in the head and dumped far from home so bodies could not be identified. Police also raped women in their houses in poor neighborhoods in and around Kasserine in the rural interior" (Chrisafis, 2011a).

Similar to Egypt, Tunisian law dictates that the president is entitled to declare a state of emergency as stated in the 1978 constitution. The amendment came about through a presidential decree and was evoked during the 2011 uprisings under by President Ben Ali. This martial law was reiterated in Article 8o in the new constitution of 2014 (Tunisian Constitution, 2014). The declaration of a state of emergency grants the state the right to suspend certain civil rights, such as the right to assembly, and transfers sol authority, temporarily, to the executive to detain and disperse any "activities are deemed to endanger security and public order ... likely to provoke or sustain disorder ... [and allows the security apparatus to] take any measure to ensure control of the public" (Human Rights Watch, 2015). Although Freedom House declared post-revolution Tunisia 'free', Amnesty International reported that:

"The authorities continued to renew the state of emergency and used it to justify imposing arbitrary restrictions on freedom of movement. Torture and other ill- treatment of detainees continued in an environment of impunity. Police carried out arbitrary arrests and house raids without judicial warrants ... [and] Prosecutions of peaceful protesters increased in several regions" (Amnesty International, 2018b:364).

Protection against different forms of violence perpetuated by the state and reproduced by the society remains inadequate. Violence in Tunisia is widespread, where "one in six married women has faced sexual violence at least once in her life, mostly by her intimate partner, In the same year 47.6

${ }^{16}$ Established by Seif El Dawla and Susan Fayad for the rehabilitation of victims of violence and conducting research on gender and women's issues in Egypt. The center was shut down by the Egyptian authorities in 2016 on the basis of not securing the proper licensing for the establishment (Read more about it: https://www.amnesty.org/en/latest/news/2017/o2/shutdown-of-renowned-torture-rehabilitation-centre-in-egypt/) 
percent of Tunisian women ages 18 to 64 had been subjected to at least one form of violence [domestic, physical, emotional, sexual] in their lives" (Office National de la Famille et de la Population, 2010:52). The social perception of women was aggravated by the existence of a loophole in the former Tunisian Penal Code, Article 227 bis, which stipulated that rapists and sexual assailants can avoid prosecution by marrying their victims. Although this Article has been removed from the constitution in 2017, these gendered declarations fostered an environment of devaluation of a woman's right to personal autonomy and her right to safety. Furthermore, sexual harassment laws in Tunisia have failed to protect women from harassers. Under Article 226(4), a law suit filed against the predator carries the potential danger of a defamation countersuit (Amnesty International, 2015a:56). This not only undermined the voices of women and their right to protection and justice, but created a culture of silence, and augmented vulnerability and marginality, especially amongst women of poorer socio-economic classes.

Nonetheless, in 2013 a legislative bill was produced by activists in coalition with the Assemblée des représentants $d u$ people for review and voting by the Rights, Liberties and Foreign Relations Commission. The Bill had set forth increased punishments for aggravated assault, rape, sexual harassment, and pedophilia, as well as stipulating the necessity of a government funded service, the National observatory on Violence against Women, and a concise definition for the aforementioned crimes within the Penal and Personal Status Codes. In 2017, that bill was accepted by the Congress (UN Women, 2017).

Despite admirable efforts by the government in Tunisia - pushing legislative rights for equality between males and females regarding inheritance (despite Shari'a law stating otherwise), constitutionally guaranteeing equality between men and women, granting women the right to initiate divorce, constitutionally guaranteeing the rights of minorities and religious freedom, broadening the definition of violence in the Penal Code to protect women, and instigating new social services to encourage victims of violence, abuse, and harassment to report their perpetrators - there is still room for improvement. The new constitution's language is vague and statutorily ambiguous, especially if applied in cases of domestic violence. Articles 218, 219, and 319 stipulate punishments for assailants, but also "provide that the prosecution, trial or execution of the sentences is cancelled if the victim spouse or descender retracts the complaint" (MRA and Advocates for Human Rights, 2017:4). According to the Tunisian Ministry of Justice report, $65-72 \%$ of cases are withdrawn or dismissed ${ }^{17}$ and approximately $29 \%$ were convicted of violence and domestic abuse (Amnesty International, 2015a:21). Furthermore, the classification of rape, in Article 227 of the Penal Code, stipulates that the crime is one against morality rather than humanity, and proceeds to state that the age of consent is 16 years old. This Article reproduces a culture where morality and social perception is superior to fundamental human rights, allowing for a perpetuation of an inferiority of victims. Moreover, the age of consent can be circumvented, in the case of marriage, if the guardian consents on behalf of child, therefore enabling and legitimizing child-marriages.

Additionally, the Penal Code as it stands contains no provision on inter-marital rape, and does not recognize the crime as what it is. Problematically, the Personal Status Code reinforces the sentiment in Article 23 where it requires spouses to "fulfill their conjugal duties according to practice and customs". As the article stands, its interpretation is open to subjective judgement on what constitutes "customs". Additionally, under Article 31 "either spouse may seek a fault-based divorce on the grounds of material or non-material harm caused. Judges will interpret harm as including

${ }_{17}$ "According to the Ministry of Justice, in the 2012-2013 judicial year, the public prosecution received 5,575 complaints of marital violence, of which some $65.8 \%(3,672)$ were either withdrawn or dismissed. Of the accepted complaints, only $28.9 \%$ (551) resulted in convictions. By comparison, in 2011-2012, the public prosecution received 5,248 complaints, of which $68.3 \%(3,583)$ were either withdrawn or dismissed, and convictions were secured in $38.9 \%$ of accepted cases (649). In 2010-2011, some $72.5 \%$ of the total number of filed complaints $(5,116)$ were either withdrawn or dismissed, and some 710 individuals were convicted of marital violence, representing approximately $50.5 \%$ of cases referred to court" (Presentation by Samia Doula, Ministry of Justice, 19 January 2015, as cited by Amnesty International, 2015a) 
domestic violence ... in theory, women victims of domestic violence can file for a fault ... in practice, however, high evidentiary requirements of either a confession by the offender or a medical certificate create barriers to women seeking divorce ... judges generally will not grant this type of divorce unless there is a criminal conviction first" (MRA and Advocates for Human Rights, 2017:6). If a woman were to call the authorities and report domestic violence, police forces have been reluctant to provide such assistance and intervene on behalf of the women, as it is viewed as a "private affair" (Canada, 2016). A widespread concern regarding the reputation of a woman and the social retribution upon reporting violence and rape have discouraged many women from reporting as social and cultural norms prohibit the 'airing of dirty laundry'. Evidently, an institutionalization of violence against women can be observed. In Tunisia it was recorded that in the absence of visible physical injury, judges would be reluctant to convict a spouse, as "in one case we had, the husband would repeatedly beat his wife on her head between his two hands until she would pass out and then have to stay in bed. When she went to the public hospital, the medical report said "there is no trace of violence we can cite." Based on this, the judge dismissed the case" (MAR and Advocates for Human Rights, 2017:7; Canada, 2016). The lack of concise definitions and social and legal protection and services for women facing domestic abuse protected under the pretense of customary social traditions and morality, will lead to an aggravation of the violence perpetuated and reproduced by the system.

\section{Success and Failure: Post-2011}

After the Arab Spring, Egypt and Tunisia were predicted to enter a democratization transition. The revolutionaries in both countries, especially the women, expected to have their demands for dignity, equality, and justice met and reflexively incorporated into the state apparatuses. Women, specifically, expected to be recognized for the role they played in the revolution, hoping that their silence would be broken and their voices heard by the post-revolutionary regimes. The fall of the authoritarian regimes brought about an ideological and political vacuum, novel to the Middle East. Yet, both countries experienced the same fate. As elections approached in both Tunisia and Egypt, political Islamists (Ennahda Party in Tunisia and the Freedom and Justice Party in Egypt) ${ }^{18}-$ known as the main opposition to the ousted regimes and its members forced to go underground to escape government prosecution prior to 2011 (Wolf, 2017:2) - saw an opportunity to gain political power. As the MB organization had a firmly established social support - acquired through charitable social services provided in and for rural areas, where the majority of the population resides - the seizure of power was relatively easy.

After the revolution in Tunisia, Ennahda party entered the political race after being systematically attacked and banned from any form of political expression. Anne Wolf (2017) distinguished between the Muslim Brotherhood in Egypt and Tunisia, arguing that Ennahda's party's identity and orientation is different from that of Egypt's Freedom and Justice party; Tunisia's Ennahda party's mission is not the establishment of an Islamic state - initially it was the expulsion of French colonial forces - but the incorporation of Islamic modernism into the governing narrative. Her account of Ennahda's political ideology presents the group as relevant and desirable to Tunisian citizens as opposed to rejectionists of secularism and modernity. The political victory of the party in 2011 with $41 \%$ majority seats in parliamentary elections (90 seats out of a total of 217 seats) was not surprising; the party's leaders and members have emphasized their commitment and adamant passion for change and political inclusion of all members of society by promising to keep the spirit and calls of the revolution alive (Fair, 2011:41). A positive indicator that women's voices would be represented in the parliament, was the $27 \%$ (61 seats) win for women on party lists. Nonetheless, the draft constitution produced in 2012 by the majority party in collaboration with minority parties was ambiguous at best. Kamala Chandrakirana. head of the UN Working Group on discrimination against women in law and in practice expressed "We are concerned at the persistence of loopholes and

\footnotetext{
${ }^{18}$ Both parties are influenced and founded on the basis of the Muslim Brotherhood's ideals and political thought.
} 
ambiguities in the current draft of the constitution which, if not removed, might undermine the protection of women's rights and the principle of gender equality," (UN News Service, 2013) adding "While equality between men and women is recognized, the prohibition of discrimination, including on the ground of sex, is not articulated in the second draft constitution, and there is a lack of provision on the right to remedy" (UN News Service, 2013).

In the years following the victory of the Islamist party, suspicion of conservatism grew. Women noticed a shift in the public sphere, where many of them were "harassed for their dress codes, for smoking, for drinking, for walking unaccompanied by male relatives or for participating in different types of protest marches" (Johansson-Nogués, 2013:402). Yet, the newly elected government was slow to react various forms of violence against women in the public and private spheres. According to The Association Tunisienne des Femmes Démocrates (ATFD) "individuals have tried to impose religious dress on unveiled students and teachers and, in some cases, used violence and intimidation" (FIDH, 2013). This is indicative of the political atmosphere in the post-2011 era and the election of an Islamist party. One could attribute this to the religious dimension the majority party introduced, which could have encouraged conservative civilians to believe they must chaperone social Islamization. Turning victims into criminals by mobilizing the judiciary posed a major threat to women of the revolution. To emphasize the inadequacy of the post-revolutionary system in Tunisia and its failure to protect women, in 2012 a woman, who was raped by members of the police force, was charged with public indecency (Ben Hassine, 2012). This is indicative of the statutory ambiguity in the proposed 2012 constitution and illuminating of Ennahda's reluctance to allow women's voices to be contributors and integral members of the governing body. The party perceived women's presence in policy-making settings as a "complementary role" (Colombo, and Voltolini, 2017:10) to their male counterparts, and attempted to "literally "re-Orient" Tunisia towards the conservative Arab world and away from its relative openness to Europe and regionally progressive stances on women's rights" (Marks, 2015:2).

In Egypt, similarly, the Muslim Brotherhood's party, Freedom and Justice, won majority seats in the parliamentary elections. Additionally, the Muslim Brotherhood member, Mohamed Morsi, ran for presidency and won the elections. Morsi became the first civilian president of Egypt since its independence in 1952. The electoral law in Egypt stipulates that a party-list must include women. In what was hoped to be a historic outcome and a step towards inclusion of women, only brought about 12 elected women into a parliament of 498 seats (El Baradei and Wafa, 2013:43). Furthermore, in 2012 a Constitutional Assembly was formed to draft the new post-revolutionary constitution. Out of the 100 members, only six were women were on the panel. The assembly was disbanded and a new one formulated, which had more women on it. Nonetheless, female panelists walked out after reporting "being intimidated by their male homologues or found their views being ignored in the drafting of the text" (Johansson-Nogués, 2013:402).

According to the head of the UN Working Group on the issue of discrimination against women in law and in practice, Kamala Chandrakirana, "despite offering unprecedented opportunities for progress, political transitions can result in regression and bring new forms of discrimination" (OHCHR, 2013:\#1312374) adding "We urge the Egyptian Government to ensure women's full and equal participation in all processes related to the political transition, to guarantee their freedom to express their views, to be protected against violence in their political and public activities and have their voices incorporated in public discourse and in shaping the society" (OHCHR, 2013:\#1312374). The 2012 constitution not only undermined the Personal Status Law and limited the change in favor of the majority of the society, but was also heavily suspicious, as "the haste with which the Constituent Assembly adopted the final text for presidential action, and many of the surrounding circumstances, have put into question the credibility of the process, and contributed to the chaos in Cairo and other cities" (United Nations Information Center in Egypt, 2012). Consequentially, a male-drafted and oriented constitution was produced that provided little to no legal and constitutional safeguards for women, ignored women's voices, and inherited the spirit of patriarchy and perpetuated female subordination and legal inequality from the pre-2011 constitution. As a result, harassment and violence against women remained eminent, and other than reformations to cater to the needs of the 
post-revolution government, not much had changed. The director of the Middle East and North Africa division of Human Rights Watch, Heba Morayef, reported that there has been "zero response" (Arrott, 2013) by the MB government to end violence against women and in fact exacerbated the crackdown on political expression, as it did not correspond to the ideology of the government (Arrott, 2013).

It is crucial to remember that "institutions claiming to be democratic are not necessarily socially just" (Agathangelou, 2011:591). As other feminist scholars have noted, in post-revolution/conflict scenarios impediment of women's issues commonly occur (Eschle, 2000; Moghadam, 2008; Dyer, 2013). Under the MB regime, there was an active effort to withdraw rights that women fought to obtain under previous regimes. As Azza Kamel, a human rights activist, noted "after the revolution, most of Egyptian society - and especially the Islamists - began attacking women's rights" (McGrath, 2012), adding that the MB is "trying to change divorce and custody laws, push FGM (female genital mutilation), and reduce the age of marriage from 18 to nine years old. We expected more" (McGrath, 2012). Azza lamented the expected failure of the revolution and the political transition as women are being systematically and intentionally excluded from the public sphere, through harassment and intimidation, and ostracized in most decision making processes. An example of such deliberate setbacks is the ideological strife of the Muslim Sisterhood (MS), a sub-committee of the Muslim Brotherhood exclusively for Muslim women. The MS was quick to label secular and Christian women's organizations and movements as 'reactionary', western-driven, and imperialistic (Khalaf, 2012) citing their alleged relationship with the former first lady, Suzanne Mubarak, as evidence of their corruption (Elsadda, 2011:85). Not only was the post-revolution Islamist regime dismantling decade-long struggles of women, but it was also intentionally excluding minorities, Jewish and Christian, from voicing and influencing their political opinion and the legal structure. It can be argued that the Othering and villainizing of women and minorities by manipulating public perception was of strategic significance for the MB regime, as without the change in perception the rescinding of legal protections for these groups would have come close to impossible.

Discrediting voices of dissent in authoritarian countries using force, literally and figuratively, coupled with inexperienced leadership styles and vindictive policy construction to inverse historic expulsion and marginalization from public endeavors and legitimate political status, affects the marginalized and vulnerable the most. Women's issues and the feminist cause have fallen prey to gendered Othering and unfounded conspiracy theories in the post-Arab Spring era of both Tunisia and Egypt. A decrease in women's agency and the barricading of voices of dissent, especially women's, for personal gain, caused the revolution to fall victim to personalized regimes. This can be applied to both cases presented here. Nonetheless, Tunisia's revolution managed to survive the expected political and administrative turmoil of the revolution, while Egypt remains the same if not worse than pre-2011. The factors that brought about the respective success and failure was primarily the institutional, legal, and judicial reform and a willingness/reluctance to secularize and democratize.

On the one hand, Tunisia has substantially reformed its polity to accommodate for the new orientation called for by the people. Although it could be argued that Tunisia is gradually transitioning to democracy, there is still room for improvement. The 2014 constitution laid out multiple electoral and political reforms: 1) it declared Tunisia a semi-presidential system and granted the majority party the freedom to nominate the head of government; 2) the Assembly of the Representatives of the People (ARP), established as set forth and protected under the 2014 constitution's unicameral legislative, has been elected and deemed by international observers as free and credible; 3) political parties, including the opposition, have the right to express divergent ideologies and philosophies unencumbered and protected by legislative reform; and 4) encouraged and supported people with disabilities and minorities to participate in the electoral process by offering them government-sponsored services. Yet, there are many hindrances to Tunisia's actualization of a true democracy. Larbi Sadiki (2019), in a policy brief, recorded some of those shortcomings, which include inadequate campaigning finance laws, which allow for voter buying; a 
reluctance of the Beji Ciad Essbesi's government to adhere to transparency laws and regulations; corruption within the government apparatus, where oligarchs connected to the Ben-Ali regime still influence economic and fiscal policymaking processes, as well as allowing for geopolitical influence over presidential and ARP elections - it has been reported that the United Arab Emirates "gifted two armored cars to Essbesi in the run-up to Tunisia's 2014 elections, and had reportedly pressured the party to crack down on Ennahda. Ennahda, in turn, is thought to receive support from Qatar, and in 2017 faced a lawsuit alleging illegal financial support from the emirate" (Freedom House, 2018a).

Furthermore, the Essbesi government seems to regress politically in favor of the Ben Ali regime. For instance, the underfunding of the legislative branch concentrated lawmaking and policymaking with the executive. Additionally, the Prime Minister, Youssef Chahed, has propelled an anticorruption campaign, through the establishment of the Truth and Dignity Commission. Although admirable effort, the commission as well as the PM himself, have repeatedly failed to persecute oligarchs. In fact, a controversial law, under his recommendation, was passed in 2017, the Administrative Reconciliation law, which "grants amnesty to individuals implicated in economic crimes under Ben Ali's regime, if they did not gain personally from those acts" (Freedom House, 2018a). Moreover, the renewal of the state of emergency by evoking the right of the president to declare the state of emergency and effectively violating Article 49 of the 2014 constitution, which guards civilians against excessive use of violence and the suspension of certain legal and constitutional rights. A proposed state of emergency bill is currently being discussing in ARP, to, which the Deputy Middle East and North Africa Director of Amnesty International, Magdalena Mughrabi, reacted by stating "If this law is approved it will give the authorities free rein to restrict human rights whenever they feel like it, seriously threatening the progress Tunisia has made since the 2011 uprising" (Amnesty International, 2019). Scholars have been wondering whether Tunisia's democracy would survive if counter-revolutionary legislations and policies were to continue being produced by the Esbessi government (Cherif, 2019; Grewal, 2019; Weilandt, 2018; Amroune, 2018).

Egypt, on the other hand, has regressed drastically since 2011. In 2013, the Supreme Council of the Armed Forces (SCAF) staged a military coup and seized power from Muslim Brotherhood elected president, Mohamed Morsi. An interim government under the supervision and monitoring of SCAF was introduced, paving the way for the 2014 presidential elections. Furthermore, a draft constitution was passed by referendum in which Articles pertaining the budgeting and monitoring of the military were relaxed, if not omitted altogether (Polimeno, 2015). The current president, Adel-Fattah El Sisi, former defense minister and commander of armed forces, abdicated his military position and ran for presidency. During the presidential elections, no international monitors were able to verify the fairness of the election, and in fact reported external financing, intimidation, arbitrary financial menacing, random arrest and assaults by military personal on civilians, as to guarantee the victory of El Sisi (Freedom House, 2018b). The Egyptian government not only tightened laws, but prevented any form of political pluralism, crushed opposition and prohibited their establishment, increased surveillance and excessive use of the coercive apparatus for the war on terrorism, subjugated the press and other media outlets to censorship and denied many independent news outlets appropriate licensing, shut down online sources of information, and above all, allowed the police to disperse any gathering of 10 or more individuals and charge them with disturbing the peace and security of the state (Freedom house, 2018b; Heliotis, 2014; Allam, 2019).

Furthermore, Egypt passed a law in 2017 Law 70 was passed by the government, which states that any civil societies and non-governmental organizations are prohibited from "conducting activities that harm national security, public order, public morality, or public health" (International Federation for Human Rights, 2017). The language used in this law is ambiguous at best and allowed for the exploitation and intensified abuse by the government over civilian and organizations that oppose the existing system. According to the deputy Middle East director at Human Rights Watch, Joe Stork, "This new law represents a huge step backward for freedom of association in Egypt," (Human Rights Watch, 2017) adding, "The Egyptian authorities have squeezed shut whatever limited space remained for nongovernmental groups in Egypt and driven the human rights community 
underground" (Human Rights Watch, 2017). Furthermore, El Sisi’s Ending Violence Against Women project, which started in 2014, has repeatedly failed to protect women, by maintaining the Personal Status Law as is, failing to establish an independent judiciary to oversee cases of abuse and rape, weakening the independence of the legislature by underfunding it to concentrate lawmaking and policy production with the executive, persecuting victims of assault and rape for public indecency, and systematically perpetuating violence against women by renewing the state of emergency and acquitting government-employed police officers, physicians, and military personal from convictions on the basis of rape, assault, and harassment (Alter, 2015; Amnesty International, 2015b; Amnesty International, 2018c).

\section{Conclusion}

In Conclusion, the adoption of a gendered framework for comparative institutional analysis has proven paramount to understanding respective shortcomings. Tunisia and Egypt's Arab Spring are the two most cited success and failure stories. Where Tunisia, at least quantitatively, has been successful in its political transition to democratization and secularization, Egypt has failed to do so, and regressed to 'old habits'. Gender relations in both countries have interchangeably assisted in the transformation of the nation. As both countries were labeled by The Freedom House as 'not free' in 2010, Tunisia's revolution and subsequent institutional reformations assisted in replacing its 'not free' status to 'free', while Egypt did not.

Throughout this research feminist voices prior, during, and post-2011 Egypt and Tunisia were presented and their significance emphasized. Where women refused to be subjugated to violence and contested their victimization - in the public sphere via the coercive apparatus and in the private sphere via domestication and forced subordination - one would expect to see change. Specifically, the personal status code/law, which governs gender relations and the private sphere, was conversely challenged and its legitimacy discontinued in the aftermath of the Arab Spring. While Tunisian women were successful, to some extent, in challenging their patriarchal systems and its subsequent institutionalization and codification, Egyptian women were not as successful. This ultimately yielded favorable results for the Tunisian population, and worsened, at best, for the Egyptian population.

The research attempted to understand the factors contributing to this success and failure, and account for contextually significant historical and present events, as well as situationally investigate the existing system. It has become evident, that gender-consciousness and the consequent construction of gender-conscious institutions to reflect public opinion and morale, are paramount, to an extent, to the success of a revolution. As women worldwide constitute half of the population in most nations, a shifting paradigm of their indispensability as co-revolutionaries and engines of change must be accounted for and accepted. The post-2011 Tunisian government realized and recognized the implication of exclusionary polities and sequential quality of policy production. Tunisia's historical anti-colonial struggle signaled revolutionary efforts and the impact of inclusion. As a politically marginalized group, the victors of the first post-2011 parliament, Ennahda party, decided to adopt an inclusionary approach to policy, therefore, dismissing and devaluating women's and feminists' voices was curtailed. The party's open-door philosophy allowed for the emergence of political and social oppositions, and a deconstruction of the patriarchal embeddedness within the legislative framework. The moderate political Islamist party has therewith paved the way for the deconstruction of archaic notions and its substitution with social egalitarian ones.

In juxtaposition, Egypt's 2011 revolution inflamed existing institutional biases and reiterated the status of the country as 'not free'. The presidential victory of the Muslim Brotherhood affiliated Mohamed Morsi and the organization's political party, Freedom and Justice, in parliamentary elections had reignited faith in reform. Yet, the lack of leadership and political experience of the civilian-president and his affiliated party, coupled with a thirst to inverse historical state-sponsored systemic brutality, repression and marginalization, resulted in the erection of polity and production of policies that were, to an extent, Brotherhood-serving. In a matter of a year, Egypt witnessed a 
military coup, which ousted the MB regime and reinstated a military state, which is de facto governed by martial law. The institutions existing in Egypt were by no means gender-conscious, and in fact were set out to systematically reproduce its patriarchal essence. The military, in most occasions, is a self-serving entity, with a purpose to serve and protect as opposed to reform and deconstruct. The military, as an institution, is a hyper-masculine, male-dominated, bureaucratic system. Its employment as a political force brings about obedience to the chain of command, a negligence to social welfare (as the main purpose is subsistence, irrespective of whether its nature), a repression of resilience to authority, and most importantly, political and social impunity. The regression of the Egyptian government to a military regime, in addition to its existing patriarchal institutions and the exasperation thereof, not only deemed the revolution a failure, but also obliterated hope for reform. If attention by the state were to be reoriented to gender inequality and state-sponsored violence, one can carefully assume it as a guise to deter international monitoring and pressures. Throughout the research it has been established that state-sponsored feminism is an instrument of the state to please global powers as opposed to genuine attempting reform.

Gender-conscious institutions can be one of many factors that have led to the respective success and failure of the Arab Spring. Although efforts have been made on behalf of the Tunisian government to address and actively reform gender biases, there is still room for improvement. As for the Egyptian population, especially their women, perhaps a unification of the society should supersede the establishment of gender-conscious institutions. As Friedrich Schiller so eloquently said, "Even the weak become strong when they are united".

\section{References}

Abu-Lughod, L. (2002). "Do Muslim Women Really Need Saving? Anthropological Reflections On Cultural Relativism and Its Others". American Anthropologist,104(3): 783-790.

Agathangelou, A. (2011). "Making Anew an Arab Regional Order? On Poetry, Sex, and Revolution". Globalization, 8(5): 581-594.

Allam, R. (2019). Egypt: Tailoring Constitutions For The Ruling Military". Lobe Log, (accessed 22 March, 2019): https://lobelog.com/egypt-tailoring-constitutions-for-the-ruling-military/

Alter, C. (2015). "Egypt's 'Token Reforms' Fail to Protect Women, Says Amnesty International". The Time, (accessed 22 March, 2019): http://time.com/3675399/egypts-reforms-to-protect-women-international/

Amar, P. (2011). "Turning the gdnered politics of the security state inside out?". International Feminist Journal of Politics, 13(3): 299-328.

Amar, P. (2011). "Turning the gendered politics of the security state inside out?" International Feminist Journal of Politics, 13(3): 299-328.

Amnesty International, (2010). "Egypt: Killing of Young Man Must Be Investigated". Amnesty International, (accessed 19 March, 2019): https://www.amnesty.org/en/press-releases/2010/o6/egypt-brutal-police-killingyoung-man-must-be-investigated/

Amnesty International, (2015a). "Obstacles to Justice". In Assaulted and Accused: Sexual and Gender-Based Violence in Tunisia. (London: Amnesty International Ltd.): 51-61.

Amnesty International, (2015b). "Circles from Hell: Domestic, Public and State Violence Against Women in Egypt”. (London: Amnesty International Ltd).

Amnesty International, (2018a). "Egypt". In Amnesty International Report 2017/18: The state of the World's Human Rights. (London: Amnesty International Ltd): 151-155.

Amnesty International, (2018b). "Tunisia”. In Amnesty International Report 2017/18: The state of the World's Human Rights. (London: Amnesty International Ltd):364-367.

Amnesty International, (2018c). "Egypt: Woman human rights defender and sexual harassment survivor sentenced for speaking out". Amnesty International News, (accessed 22 March, 2019): https://www.amnesty.org/en/latest/news/2018/og/egypt-woman-human-rights-defender-and-sexualharassment-survivor-sentenced-for-speaking-out/

Amnesty International, (2019). "Tunisia Repressive state of emergency bill a threat to human rights". Amnesty International, (accessed 26 March, 2019): https://www.amnesty.org/en/latest/news/2019/o3/tunisiarepressive-state-of-emergency-bill-a-threat-to-human-rights/ 
Amroune, B. (2018). "Opinion: Is Tunisian democracy in danger of collapse?" Deutsche Welle, (accessed 23 Marc, 2019): https://www.dw.com/en/opinion-is-tunisian-democracy-in-danger-of-collapse/a-42138097

Anderson, L. (2011). "Democracy, Authoritarianism, and Regime Change in the Arab World". Middle East Center: public lecture. (London: London School of Economics and Political Science):http://www.lse.ac.uk/assets/richmedia/channels/publiclecturesandevents/transcripts/20110713_183 o_changeinthemiddleeast_tr.pdf

Arkoun, M. (1994). Rethinking Islam: Common Questions, Uncommon Answers. Lee, R.D (trans.), (Boulder: Westview Press): 25.

Arrott, E. (2013). "Rising Violence Against Egyptian Women Worries Rights Activists". Voices of America, (accessed 22 March, 2019): https://www.voanews.com/a/rising-violence-against-egyptian-women-worries-rightsactivists/1577020.html

Badran, M. (1991). "Competing Agenda: Feminists, Islam and the State in Nineteenth- and Twentieth-Century Egypt”. In Kandiyoti, D. (ed.) Women, Islam and the State. (Philadelphia: Temple University Press): 201-236.

Badran, M. (2005). "Between secular and Islamic feminism/s: Reflections on the Middle East and beyond". Journal of Middle East women's studies, 1(1): 6-28.

Bayard de Volo, L. (2012). "A revolution in the binary? Gender and the oxymoron of revolutionary war in Cuba and Nicaragua". Signs: Journal of Women in Culture and Society, 37(2): 413-439.

Bellin, E. (2004). "The Robustness of Authoritarianism in the Middle East: Exceptionalism in Comparative Perspective". Comparative Politics, 36(2): 139-157.

Ben Hassine, W. (2012). "Opinion: Tunisia's response to police rape puts human rights to shame”. CNN, (accessed 21 March, 2019): https://edition.cnn.com/2012/10/04/opinion/ben-hassine-tunisia-human-rights/index.html

Black, I. (2010). "Amnesty International censures Tunisia over human rights,". The Guardian, (accessed 12 March, 2019): https://www.theguardian.com/world/2010/jul/13/amnesty-criticises-tunisia-human-rights

Brown, N. (2013). “Tracking the 'Arab Spring': Egypt's Failed Transition”. Journal of Democracy, 24(4): 45-58.

Canada: Immigration and Refugee Board of Canada, (2016). "Tunisia: Domestic violence, including legislation, state protection, and support services (2012-November 2015)". Refworld UNHCR, (accessed 21 March, 2019): https://www.refworld.org/docid/56a783044.html

Celis, K., Kantola, J., Waylen, G., and Weldon, S.L. (2013). "Introduction: Gender and Politics: A Gendered Word, a Gendered Discipline". In The Oxford Handbook of Politics and Gender. (Oxford: Oxford University Press): 128.

Cherif, Y. (2019). “Can Tunia's Democracy Survive?”. Project Syndicate, (accessed 22 Marc, 2019): https://www.project-syndicate.org/commentary/tunisian-democracy-in-crisis-by-youssef-cherif-2019-01

Chrisafis, A. (2011). "Tunisia Protests: 'The fear has gone ... I've been waiting 20 years for today". The Guardian, (accessed 21 March, 2019): https://www.theguardian.com/world/2011/jan/14/tunisia-protests-tunis-ben-ali

Chrisafis, A. (2011a). "Confusion, Fear and Horror in Tunisia as old regime's militia carries on the fight". The Guardian, (accessed 21 March, 2019): https://www.theguardian.com/world/2011/jan/16/tunisia-gun-battlearmy-tunis

Colombo, S. and Voltolini, B. (2017). "The EU's Engagement with 'Moderate' Political Islam: The Case of Ennahda”. LSE Middle East Centre Paper Series, 19: 6-18.

Connell, R. W., and Messerschmidt. J. (2005). "Hegemonic Masculinity: Rethinking the Concept". Gender and Society, 19 (6): 829-859.

Cooke, R. (2015). “Interview - Nawal El Saadawi: 'Do You feel Liberated?' I feel I am not”'. The Guardian (accessed 11 March, 2019): https://www.theguardian.com/books/2015/oct/11/nawal-el-saadawi-interview-do-you-feelyou-are-liberated-not

Dalmasso, E. and Cavatorta, F. (2010). "Reforming the family code in Tunisia and Morocco: The struggle between religion, globalisation and democracy". Totalitarian Movements and Political Religions, 11(2): 213-228.

Dyer, E. (2013). "The Marginalization of Women from Politics". In Marginalizing Egyptian Women: The Restriction of Women's Rights under the Muslim Brotherhood. (London: The Henry Jackson Society): 52-66.

El Baradei, L. and Wafa, D. (2013). "Women in the Second Egyptian Parliament Post the Arab Spring: Do They Think They Stand a Chance?". Journal of International Women's Studies, 14(3), 42-63

El Nadim Team, (2006). "Torture in Egypt: A State Policy 2003-2006". El Nadim Center for the Management and Rehabilitation of victims of Violence and torture. (Cairo: $\mathrm{Al}$ Nadeem): https://www.alnadeem.org/en/content/torture-egypt-state-policy-facts-and-testimonies-2003---2006

Elsadda, H. (2011). "Women's rights activism in post-Jan25 Egypt: Combating the shadow of the first lady syndrome in the Arab World". Middle East Law and Governance, 3(1-2), 84-93.

Eschle, C. (200o). "Engendering global democracy". Studies in Social and Political Thought, 3:349-361. 
European Convention on Human Rights (2019). "Right to Liberty and Security". Euproean Court of Human Rights, (accessed online): https://www.echr.coe.int/Documents/Guide_Art_5_ENG.pdf

Fair, E. (2011). "The Election of Ennahda Party and the Future of Tunisian Democracy". Stanford Journal of International Relations, 13(1): 40-43.

Fawcette, L. (2017). "States and sovereignty in the Middle East: myths and realities". International Affairs, 93(4): 789-807.

Freedom House (2018a). "Freedom in the World 2018: Tunisia". Freedom House, (accessed 12 March, 2019): https://freedomhouse.org/report/freedom-world/2018/tunisia

Freedom House, (2011a). "Freedom in the World 2011: Tunisia". Freedom House, (accessed 12 March, 2019): https://freedomhouse.org/report/freedom-world/2011/tunisia

Freedom House, (2011b). "Freedom in the World 2011: Egypt". Freedom House, (accessed 12 March, 2019): https://freedomhouse.org/report/freedom-world/2011/egypt

Freedom House, (2018). "Freedom in the World 2018). Freedom House, (accessed 12 March, 2019): https://freedomhouse.org/report/freedom-world/freedom-world-2018

Freedom House, (2018b). "Freedom in the World 2018: Egypt". Freedom House, (accessed 12 March, 2019): https://freedomhouse.org/report/freedom-world/2018/egypt

Giacomo, C. (2012). "Women Fight to Define the Arab Spring". New York Times, (accessed March 11, 2019): https://www.nytimes.com/2012/11/11/opinion/sunday/women-fight-to-define-the-arab-spring.html

Goldstone, J. (2011). "Understanding the Revolutions of 2011 Weakness and Resilience in Middle Eastern Autocracies". Foreign Affairs, 90(3): https://www.foreignaffairs.com/articles/middle-east/2011-0414/understanding-revolutions-2011

Gordon, J. (1992). "Revolutionary Jurisprudence". In Nasser's Blessed Movement: Egypt's Free Officers and the July Revolution, (Oxford: Oxford University Press):58-78.

Goulding, K. (2011). “Tunisia: Women's winter of discontent”. OpenDemocracy: Free Thinking for the World, (accessed 12 March, 2019): www.opendemocracy.net/505o/kristine-goulding/tunisia-womens-winter-ofdiscontent

Grami, A. (2008). "Gender equality in Tunisia”. British Journal of Middle Eastern Studies 35(3):349-361.

Grami, A. (2018). "Women, Feminism and Politics in Post-Revolution Tunisia: Framings, Accountability and Agency on Shifting Grounds". Feminist Dissent, 3:23-56.

Grewal, S. (2019). "Tunisian Democracy at Crossroads". Policy Brief: Foreign Policy at Brookings. (Washington: Brookings Institution): 1-12.

Hawkins, M. (2018). "Huda Shaarawi: Egyptian feminist who started a revolution". BBC News UK, (accessed 11 March, 2019): https://www.bbc.co.uk/news/av/world-africa-44814874/huda-shaarawi-egyptian-feministwho-started-a-revolution

Heliotis, N. (2014). "A Textual Analysis of Presidential Power under the 2014 Egyptian Constitution". The International Lawyer, 48(2), 127-151.

Hope, B. (2011). "One year on, Egypt remembered violent death of Khalid Said". The National - Abu Dhabi, (accessed 19 March, 2019): https://www.thenational.ae/world/mena/one-year-on-egypt-remembers-violentdeath-of-khalid-said-1.420338

Human Rights Watch, (1959). "Tunisia: Emergency Shouldn't Trump Rights: Sweeping Powers to Bar Demonstrations; Control the Media". Human Rights Watch, (accessed 21 March, 2019): https://www.hrw.org/news/2015/o7/o7/tunisia-emergency-shouldnt-trump-rights

Human Rights Watch, (2017). "Egypt: New Law Will Crush Civil Society - Many Groups Likely to Close Despite Growing Need for Services". Human Rights Watch, (accessed 22 March, 2019): https://www.hrw.org/news/2017/o6/o2/egypt-new-law-will-crush-civil-society

Ikhwanweb, (2013). "Muslim Brotherhood Statement Denouncing UN Women Declaration for Violating Sharia Principles". IkhwanWeb, (accessed 14 March, 2019): http://www.ikhwanweb.com/article.php?id=30731

International Commission of Jurists, (2012). "Rule of Law and Separation of Powers" In Egypt's New Constitution: A Flawed Process; Uncertain outcomes. (Geneva: International Commission of Jurists): 19-22.

International Federation of Human Rights (FIDH) (2011). "Interview with Amal Abdel Hadi, New Woman Foundation, Egypt: 'Previous claims that women's voices should not be heard, all of this has been smashed during the revolution"'. International Federation of Human Rights, (accessed 11, March, 2019): www.fidh.org/Interview-with-Amal-Abdel-Hadi-New-Woman

International Federation of Human Rights, (2013). "Tunisia". ArabWomen Spring: FIDH, (accessed 21 March, 2019): http://arabwomenspring.fidh.net/tunisia-en

International Federation for Human Rights (2017). "Egypt: New Law Will Cripple Egyptian NGOs". International Federation for Human Rights, (accessed 11 March, 2019): https://www.refworld.org/docid/593a5d254.html 
Johansson-Nogués, E. (2013). "Gendering the Arab Spring? Rights and (in)security of Tunisian, Egyptian and Libyan women”. Security Dialogue, 44(5-6): 393-409.

Joseph, S. (2012). “Thinking intentionality: Arab women's subjectivity and its discontents”. Journal of Middle East Women's Studies, 8(2): 1-25.

Kendall-Taylor, A., Frantz, E., and Wright, J. (2017). "The global Rise of Personalized Politics: It's Not Just Dictators Anymore”. The Washington Quarterly, (Spring): 7-19.

Kessler, S. J., Ashenden, D. J., Connell, R.W., and Dowsett, G.W., (1982). Ockers and disco-maniacs. (Sydney, Australia: Inner City Education Center).

Khalad, R. (2012). "The Muslim Sisterhood". Financial Times, (accessed 22 March, 2019): https://www.ft.com/content/167164a6-1e34-11e2-8e1d-oo144feabdco

Khlebnikov, A. (2016). "Why did the 2011 Egyptian Revolution Fail?". Central European Journal of International and Security Studies, 10(3): 88-117.

Kirkpatrick, D. (2018). "Overlooked No More: Doria Shafik, Who Led Egypt's Women's Liberation Movement". New York Times, (accessed 11 March, 2019): https://www.nytimes.com/2018/o8/22/obituaries/doria-shafikoverlooked.html

Mansouri, F. and Armillei, R. (2016). "The democratic 'transition' in post-revolution Tunisia: conditions for successful 'consolidation' and future prospects" R/evolutions: global trends \& regional issues, 4(1): 156-181.

Marks, M. (2012). "Islamism and Uncertainty: Charting the Future of Women's Rights in Tunisia". St Antony's International Review, 7(2):120-138.

Marks, M. (2015). “Tunisia's Ennahda: Rethinking Islamism in the context of ISIS and the Egyptian coup”. Working paper for Project on U.S. Relations with the Islamic World for Brookings Institution. (Washington: Brookings Institution): 1-2.

McGrath, C. (2012). "Egypt Revolution Makes it Worse for Women". Inter Press Service (IPS) News From the Global South, (accessed 22 March, 2019): http://www.ipsnews.net/2012/10/egypt-revolution-makes-it-worse-forwomen/

Mhajne, A. and Whetstone, C. (2018). "The use of political motherhood in Egypt's Arab Spring uprising and aftermath". International Feminist Journal of Politics, 20(1):54-68.

Mobilizing for Rights Associates (MRA) and The Advocates for Human Rights, (2017). "Tunisia: Women's Rights Joint Stakeholder Report for the United Nations Universal Periodic Review". (accessed 21 March, 2019): https://www.theadvocatesforhumanrights.org/uploads/tunisia_upr_april_may_2017_review.pdf

Moghadam, V.M., (2008). "Democracy and Women's Rights: Reflections on the Middle East and North Africa". Paper presented at the Comparative Studies on Family Democratization and Socio-Politics, in Buenos Aires, 24-26 September 2008.

Mohsen, H. (2012). "What made her go there? Samira Ibrahim and Egypt's virginity test trial". Al Jazeera, (accessed 21 March, 2019): https://www.aljazeera.com/indepth/opinion/2012/03/201231613312920185o.html

Mulrine, C. (2011). "Women's organizations in Tunisia: Transforming feminist discourse in a transitioning state". Independent Study Project (ISP) Collection Paper 1136: http://digitalcollections.sit.edu/isp_collection/1136/

Office National de la Famille et de la Population, (2010). Enquête Nationale sur la Violence a l'Egard des Femmes en Tunisia: Rapport de l'enquête, (accessed 21 March, 2019): http://www.medcities.org/documents/10192/54940/Enquête+Nationale+Violence+envers+les+femmes+Tunisie+2010.pdf

Philipp, Thomas, 1978. "Feminism and Nationalist Politics in Egypt". In Beck, L. and Keddie, N. (eds.) Women in the Muslim World. (Cambridge: Harvard University Press): 260-284.

Pitkin, H. (1972). The concept of Representation. (Los Angeles: University of California Press).

Polimeno, M. (2015). "The 2014 Egyptian constitution: balancing leadership with civil rights (al - madaniyya)". Electronic Journal of Islamic and Middle Eastern Law, 3: 1- 67.

Rose, M. (2015). "Education in North Africa Since Independent - Country Profile: Tunisia". English Agenda: British Council, (accessed 12 March, 2019): https://englishagenda.britishcouncil.org/sites/default/files/attachments /education-in-north-africa-since-independence-tunisia.pdf

Sadiki, L. (2019). "Regional Development in Tunisia: The Consequence of Multiple Marginalization". Policy Briefing: Brookings Doha Centre, (Doha: Brookings Institute): 1-13.

Sika, N. and Khodary, Y. (2012). "One step forward, two steps back? Egyptian women within the confines of authoritarianism". Journal of International Women's Studies, 13: 91-10o.

Stepan, A. (2012). "Tunisia's Transition and the "Twin Tolerations". Journal of Democracy, 23(2): 89-103..

Stiehm, J. (1982). "The protected, the protector, the defender”. Women's Studies International Forum, 5(3/4):367376. 
Tadros, M. (2010). "Egypt". In Kelly, S. and Breslin, J. (eds) Women's Rights in the Middle East and North Africa: Progress Amid Resistance. (Lanham, MD: Rowman and Littlefield): 89-120.

Tickner, J.A. (1992). Gender in International Relations: Feminist Perspectives on Achieving Global Security. (New York: Columbia University Press).

Tignor, R. (1966). "British Administration and Other Agents Of Modernization". In Modernization and British Colonial Rule in Egypt, 1882-1914, (Princeton University Press): 358-374.

Tunisian Constitution, (2014). Constitution. United Nations Development Program (trans.) https://www.constituteproject.org/constitution/Tunisia_2014.pdf

UN Women, (2017). "Tunisia passes historic law to end violence against women”. UN Women, (accessed 21 March, 2019): http://www.unwomen.org/en/news/stories/2017/8/news-tunisia-law-on-ending-violence-against-women

United Nations Human Rights: Office of the High Commissioner, (n.d.). "View the ratification status by country or by treaty". United Nations Human Rights: Office of the High Commissioner, (accessed 19 March, 2019): https://tbinternet.ohchr.org/_layouts/TreatyBodyExternal/Treaty.aspx?CountryID=54\&Lang=EN

United Nations, (2012). "UN experts urge review of Egypt's draft constitution to ensure equality and women's rights". UN News, (accessed 21 March, 2019): https://news.un.org/en/story/2012/12/428352-un-experts-urgereview-egypts-draft-constitution-ensure-equality-and-womens

United Nations Information Center for Egypt (2012). “UN Officials Voice Alarm at Egyptian Violence, Cites 'Major' Problems with Draft Constitution", UN Information Center for Egypt, (accessed 21 March, 2019): http://www.unic-eg.org/eng/?p=5002

United Nations News Service, (2013). "Tunisia must adopt stronger measures to combat gender discrimination UN experts". UN News, (accessed 21 March, 2019): https://www.refworld.org/docid/5of66b7a2.html

Weilandt, R. (2018). "Socio-Economic Challenges to Tunisia's Democratic Transitions". European View, 17(2): 210217.

Wolf, A. (2017). "Beyond the Secular Myth". In Political Islam in Tunisia: A History of Ennahda. (Oxford: Oxford University Press): 1-22.

Yahya, M. (2016). "Great Expectations in Tunisa". Carnegie Middle East Center, (Washington: Carnegie Endowment for International Peace): 10-23.

Young, I.M. (2003). "The logic of masculinist protection: Reflections on the current security state". Signs: Journal of Women in Culture and Society, 29(1): 1-25.

Zayed, D. (2011). "Attack on Egyptian women protesters sparks uproar". Reuters, (accessed 21 March, 2019): https://www.reuters.com/article/us-egypt-protests-women/attack-on-egyptian-women-protesters-sparkuproar-idUSTRE7BK1BX20111221 